\title{
MOLECULAR PROFILE, PURITY AND PRESENCE OF TRYPSIN INHIBITORS IN COWPEA PROTEIN ISOLATES ${ }^{1}$
}

\author{
KAROLINE DE MACÊDO GONÇALVES FROTA ${ }^{2 *}$, LAYS ARNAUD ROSAL LOPES ${ }^{2}$, IZABEL CRISTINA VERAS \\ SILVA ${ }^{2}$, JOSÉ ALFREDO GOMES ARÊAS ${ }^{3}$
}

\begin{abstract}
The most-used preparation process of protein isolates (PI) involves the isoelectric precipitation of the protein. Heating shortens the preparation time but this procedure may affect the purity, yield, molecular profile of the protein, and the activity of the trypsin inhibitor. This study aimed to investigate the effect of heating in the production of cowpea protein isolates. Crude whole beans (WB) were defatted with hexane, and the protein isolates obtained by isoelectric precipitation with (HPI), and without (NHPI) heating. The protein content of the WB and the PI was determined by the micro-Kjeldahl method, and the extraction yield estimated from the protein content at the end of extraction in relation to this content in the raw material. Possible losses of protein fractions were followed by SDS-PAGE, and the trypsin inhibitor activity determined by an enzymatic assay (BAPNA: benzoyl-DL-arginine-p-nitroanilide). Protein content in HPI was $83.3 \%$, less than in the NHPI (92.2\%). The HPI yield was lower (40.0\%) as compared to the NHPI (42.3\%). Electrophoresis indicated bands ranging from 13 to $262 \mathrm{kDa}$ in WB; and the NHPI presented a protein fraction's profile closer to that of the WB than to the HPI. The WB had the trypsin inhibitor activity, expressed as Trypsin Inhibitory Units (TIU), of $32.5 \pm 0.5 \mathrm{TIU} / \mathrm{mg}$-protein; HPI showed $12.7 \pm 0.5 \mathrm{TIU} / \mathrm{mg}$-protein (39\% of that observed in WB) and the NHPI, $8.3 \pm 0.2 \mathrm{TIU} / \mathrm{mg}$-protein $(25.5 \%)$. Heating reduces the yield and purity of proteins in the isolates. However, the inhibitory activity of trypsin cowpea is most affected by the isolation procedure.
\end{abstract}

Keywords: Vigna unguiculata. Trypsin inhibitor. Protein isolate.

\section{PERFIL MOLECULAR, PUREZA E ATIVIDADE DO INIBIDOR DE TRIPSINA EM ISOLADOS PROTEICOS DE FEIJÃO-CAUPI}

RESUMO - O processo mais utilizado na preparação de isolado proteico (IP) envolve a precipitação isoelétrica da proteína. O aquecimento abrevia o tempo de preparo dos isolados. Entretanto, esse procedimento pode afetar a pureza, rendimento, perfil molecular da proteína e presença do inibidor de tripsina. Este trabalho objetivou investigar o efeito do aquecimento na produção de IP de feijão-caupi. O feijão integral (FI) cru foi moído e desengordurado com hexano e o IP foi obtido por precipitação isoelétrica com aquecimento (IPCA) e sem aquecimento (IPSA). Determinou-se o teor proteico do FI, e dos isolados pelo método de micro-Kjeldahl. Estimou-se o rendimento da extração, pela massa de proteína ao final da extração em relação à existente inicialmente no material seco. Possíveis perdas de frações proteicas foram avaliadas por eletroforese SDS-PAGE. A atividade inibitória da tripsina foi avaliada em ensaio enzimático (BAPNA: benzoil-DLarginina-p-nitroanilida). Obteve-se um IPCA (83,3\% de proteína), menos puro que o IPSA (92,2\%). O rendimento do IPCA foi menor $(40,0 \%)$ em relação ao IPSA (42,3\%). A eletroforese indicou bandas variando de 13 a $262 \mathrm{kDa}$ no FI, o IPSA apresentou um perfil de frações proteicas mais próximo ao FI que o IPCA. O FI apresentou atividade inibitória, expressa em Unidades Inibitórias de Tripsina (UIT) de $32,5 \pm 0,5 \mathrm{UIT} / \mathrm{mg}$-proteína, o IPCA apresentou 12,7 $\pm 0,5 \mathrm{UIT} / \mathrm{mg}$-proteína (39\% do observado no FI) e, o IPSA, $8,3 \pm 0,2$ UIT/mg-proteína (25,5\%). O aquecimento reduz o rendimento e a pureza da proteína nos isolados. Entretanto, a atividade inibitória da tripsina é mais afetada pelo processo de isolamento.

Palavras-chave: Vigna unguiculata. Inibidor de tripsina. Proteína isolada.

\footnotetext{
${ }^{*}$ Corresponding author

${ }^{1}$ Received for publication in 08/12/2016; accepted in 03/02/2017.

Paper approved from IV CONAC 2016.

Paper extracted from the dissertation master of the first author.

${ }^{2}$ Department of Nutrition, Universidade Federal do Piauí, Teresina, PI, Brazil; karolfrota@ufpi.edu.br, lays_rosal@hotmail.com, izabelveras@outlook.com.

${ }^{3}$ Faculty of Public Health, Department of Nutrition, Universidade de São Paulo, São Paulo, SP, Brazil; jagareas@usp.br.
} 


\section{INTRODUCTION}

Cowpea [Vigna unguiculata (L.) Walp] is a legume seed of African origin grown mainly in tropical and subtropical regions and widely distributed throughout the world. It represents an important source of protein for the population, especially in the lower income segment (ELHARDALLOU et al., 2015; FROTA; SOARES; AREAAS, 2008; SING et al., 1997). However, the nutritional use of legume proteins is impaired by the anti-nutritional factor as trypsin inhibitors, tannins, and saponins (RUSSO; REGGIANI, 2015).

Protein isolation reduces the presence of such factors, and it has been widely used to increase protein recovery from the seeds for further use in foods (BOYE; ZARE; PLETCH, 2010; HORAX et al., 2004; SARWAR; XIAO; COCKELL, 2012). Moreover, protein isolates or protein concentrates are widely employed in food products manufacture due to their nutritional and functional properties (BUTT; BATOOL, 2010; WITHANA-GAMAGE et al., 2011). It was demonstrated that protein isolates from cowpea present anti-oxidant and hypocholesterolemic effects (FROTA et al., 2008; FROTA et al., 2015; MARQUES et al., 2015).

Trypsin inhibitors are anti-nutritional factors commonly found in legume seeds, and they act inhibiting or reducing the action of digestive enzymes (FRIEDMAN; BRANDON, 2001). When trypsin inhibitors are present in foods, their proteins are not completely digested and absorbed and the trypsin inhibitor itself remains in the digestive tract. Hence, these inhibitors through a series of interactions may participate of complex non digestible networks that include other cowpea proteins, increasing the problem of low protein recovery of these seeds (DUARTE et al., 2010).

Heating is an alternative for the reduction in trypsin inhibitors in beans. However, studies carried out with several cultivars, demonstrated wide variety of the inhibitory activity of trypsin resistant to thermal treatment (DUARTE et al., 2010; JOURDAN; NOREÑA; BRANDELLI, 2007; KALPANADEVI; MOHAN, 2013; LAJOLO; GENOVESE, 2002; RAYAS-DUARTE; BERGERON; NIELSEN, 1992).

Rangel et al. (2004) observed that heating in the protein during the isolation process promoted a trypsin activity reduction in the isolated protein. However, it is also known that temperature is among the main factors that interfere in the protein quality and yield of the final isolate, besides protein concentration, $\mathrm{pH}$, ionic strength, and residence time in the solubilization and coagulation steps (WAGNER; SORGENTINI; ANÕN, 2000).

The objective of this work was to investigate whether heating during the precipitation step interferes in purity, yield, molecular profile and activity of trypsin inhibitors in the production of protein isolates from cowpea cv BRS Milênio.

\section{MATERIAL AND METHODS}

Cowpea (Vigna unguiculata L. Walp.), cultivar BRS Milênio, was provided by Embrapa Meio-Norte, Teresina, PI, Brazil. The bean was ground using a hammer mill (model MML-100 Astecma - Brasil), with an internal sieve of $1.0 \mathrm{~mm}$ diameter (tyler 16), producing a powder of the raw whole bean (WB). This powder was defatted with hexane in the proportion 1:6 (w/v) to reduce lipids to approximately $27 \%$ of the initial content to a value less than $1 \%(0.61 \mathrm{~g} / 100 \mathrm{~g})$. This final powder remained $24 \mathrm{~h}$ in a fume cupboard to remove the solvent and later dried in an air oven for $2 \mathrm{~h}$ at $50{ }^{\circ} \mathrm{C}$, and sieved ina a $0.42 \mathrm{~mm}$ sieve.

The protein isolation methodology proposed by Wright and Bumstead (1984) was used, with some modification. In the protein isolation without heating, the whole bean flour, obtained as described above, was stirred during $2 \mathrm{~h}$ at room temperature in a low ionic strength buffer $(50 \mathrm{mM}$ Tris- $\mathrm{HCl}$ and $200 \mathrm{mM} \mathrm{NaCl}, \mathrm{pH} 8.5), 1: 10(\mathrm{w} / \mathrm{v})$ to solubilizing the protein. This mixture was filtered through muslin, and the residue discarded. The filtrate was centrifuged at $10,000 \mathrm{~g}$ for 20 minutes, and the precipitate removed. The filtrate had then the $\mathrm{pH}$ adjusted to 4.5 (vicilin isoelectric point) with $\mathrm{HCl} 1 \mathrm{M}$. This mixture was kept under refrigeration $\left(4{ }^{\circ} \mathrm{C}\right)$ for $12 \mathrm{~h}$ for precipitating the protein. After this stage, the suspension was centrifuged at $10,000 \mathrm{~g}$ for 20 minutes. The insoluble fraction after this last step is the cowpea protein isolate, which was then collected and lyophilized. In the isolation with heating, the mixture was kept at $80{ }^{\circ} \mathrm{C}$ (RANGEL et al., 2004) for 5 minutes after $\mathrm{pH}$ adjustment to 4.5 . All other steps were identical to the ones for isolation without heating.

Protein content was determined by the micro-Kjeldahl method (AOAC, 2007), using 6.25 as the nitrogen conversion factor. Extraction yield was assessed by the protein content in the isolate in relation to this content in the dry raw material, according to the equation:

$$
\text { Yield }(\%)=\frac{\text { Protein content in the isolate }}{\text { Protein content in the dry raw material }} \times 100
$$

For the extraction of trypsin inhibitors, $1 \mathrm{~g}$ of the whole bean flour (WB) or of the isolates with (HIP) or without (NHIP) heating, $50 \mathrm{~mL} \mathrm{NaOH} 0.01 \mathrm{~N}$ was added, and the mixture stirred for three hours at room temperature. The suspension was then centrifuged at $30,000 \times g$ for 30 minutes at $4{ }^{\circ} \mathrm{C}$ and the supernatant used for measuring the inhibitory activity according to Kakade, Simons and Liener (1969), with modification, using benzoyl-DL-arginine-p-nitroanilide (BAPNA) as the 
substrate. Absorbance was measured at $410 \mathrm{~nm}$, against a blank with previous addition of acetic acid before BAPNA. One unit of trypsin activity was arbitrarily taken as each 0.01 absorbance unit at $410 \mathrm{~nm}$ per $10 \mathrm{~mL}$ of the reaction medium per minute. Results were expressed as Trypsin Inhibitory Units (TIU) per gram of protein, being 1 TIU the responsible for the inhibition of 1 trypsin arbitrary unit.

Poli acrylamide gel electrophoresis with sodium dodecyl sulphate (SDS-PAGE) was done according to Laemmli (1970). The concentration gel was made with $4 \%$ acrylamide in Tris- $\mathrm{HCl}$ buffer $\mathrm{pH} 6.8$, and the analysis gel with $10 \%$ acrylamide in Tris-HCl buffer $\mathrm{pH}$ 8.8. The runs were performed with an electrophoresis equipment (Amersham Biosciences, Uppsala, Sweden, model Hoefer miniVE); gel dimensions were $8 \mathrm{~cm} \mathrm{x} 9 \mathrm{~cm} \mathrm{x}$ $1.0 \mathrm{~mm}$. Proteins were extracted from the samples in a buffer containing SDS, mercaptoethanol and urea, for complete dissociation and denaturation of the proteins. The electrophoresis was performed in $50 \mu \mathrm{g}$ protein per well, amperage of $20 \mathrm{~mA}$ and selfadjusted voltage up to $300 \mathrm{~V}$. After the run, the gels were stained with $0.025 \%$ Comassie Brilliant Blue solution in $40 \%$ methanol and $7 \%$ acetic acid, being destained by the same solvent. Molecular mass standards employed were: myosin (200 kDa), betagalactosydase $(115 \mathrm{kDa})$, bovine serum albumin
(96 kDa), ovalbumin (52 kDa), carbon anhydrase (30 kDa), soya trypsin inhibitor $(29 \mathrm{kDa})$, and lysozyme $(20 \mathrm{kDa})$. The electrophoresis images were analysed in the software ImageJ v. 1.50i (National Institutes of Health, USA - http://imagej.nih.gov/ij), for determination of the molecular masses.

Relative percents of each peak were obtained by the optical density of each spot, clearly identified. The molecular masses were calculated as:

$$
\log (\mathrm{y})=\mathrm{a}+\mathrm{b} \cdot \mathrm{MM}
$$

being,

$y$ : distance from the spot from the origin in $\mathrm{cm}$; $\mathrm{a}$ and $\mathrm{b}$ : constants obtained by linear regression; $\mathrm{MM}$ - molecular masses in $\mathrm{kDa}$.

All determination was performed in triplicate samples. The data were subjected to variance analysis (ANOVA), and all means and standard deviation were obtained for the assessed variables. Similarity between variables was detected by the Student $t$ test, and correlation by the Tukey test. All statistical tests were performed at $\mathrm{p}<0.05$.

\section{RESULTS AND DISCUSSION}

Protein contents of the raw whole bean flour and of the protein isolates, with (HPI) and without (NHPI) heating are shown in Table 1.

Table 1. Protein contents and yields of the whole bean cowpea flour and of the isolates with (HPI) and without (NHPI) heating, on a dry basis.

\begin{tabular}{lcc}
\hline Sample & Total protein $(\%)^{*}$ & Extraction yield $(\%)^{* *}$ \\
\hline Whole bean cowpea flour & $24.4 \pm 0.5^{\mathrm{c}}$ & - \\
HPI & $83.3 \pm 0.4^{\mathrm{b}}$ & $40.0 \pm 0.2^{\mathrm{b}}$ \\
NHPI & $92.2 \pm 0.1^{\mathrm{a}}$ & $42.3 \pm 0.2^{\mathrm{a}}$ \\
\hline
\end{tabular}

***Significant at $\mathrm{p}<0.05$ in Tukey's test and the Student's $t$-test, respectively. Different letters in the same column indicate statistically significant difference.

The requirements for the denomination "protein concentrate" is the minimum of $65 \%$ protein after all isolation steps and drying. The denomination of "protein isolate" requires a minimum of $90 \%$ protein (UZZAN, 1988). Therefore, we obtained a protein isolate only in the procedure without heating $(92.2 \%)$. Both the extraction yield and protein content were higher without heating at $80{ }^{\circ} \mathrm{C}$ during the isolation process. (Table 1).

These results are similar to those described by Deak and Johnson (2007), who obtained soybean protein isolates with 88.2 and $92.8 \%$ of protein, with and without heating, respectively, and extraction yield of 63.3 and $71.9 \%$, respectively. These same authors observed no significant difference in protein content and yield at temperatures between 25 and $60{ }^{\circ} \mathrm{C}$. However, significant reductions in both were observed when the temperature reached $80{ }^{\circ} \mathrm{C}$. Wang (2011) observed in the protein isolation from mungo beans, extraction yields between 62 and $72 \%$, with increasing the extraction temperature up to $30{ }^{\circ} \mathrm{C}$, and a decrease thereafter. Peyrano, Speroni and Avanza (2016) obtained protein contents in the isolates from cowpea (Cuaretón cultivar) of 91.5 and $92.5 \%$, and an extraction yield of 56 and $62 \%$ than those obtained in the current study. These authors employed temperatures between 70 and $90{ }^{\circ} \mathrm{C}$ during 10, 20 and 30 minutes. This heating process made a protein fraction of $42 \mathrm{kDa}$ to disappear, and promoted a time-dependent reducion of the intensity of the $80 \mathrm{kDA}$ fraction.

In the current study, heating promoted the upsurge of protein spots of high and low molecular masses $(151,101,82,47$ e $9 \mathrm{kDa})$, as compared to the raw whole seed cowpea flour (Figure 1 and Table 2). The protein isolate without heating (NHPI) presented high similarity to the raw whole seed flour with only two low-molecular weight protein spots missing after isolation (Figure 1 and Table 2). This 
can be due to higher sensitivity of these two fractions during isolation. The heated isolate, however, presented new fractions at 28 and $90 \mathrm{kDa}$, which were produced by aggregation $(90 \mathrm{kDa})$ or degradation $(28 \mathrm{kDa})$ of the original protein
(Figure 1 and Table 2). This shows the higher efficiency of precipitation of these bands, and in a production of a distinctive pool of proteins after isolation upon heating.

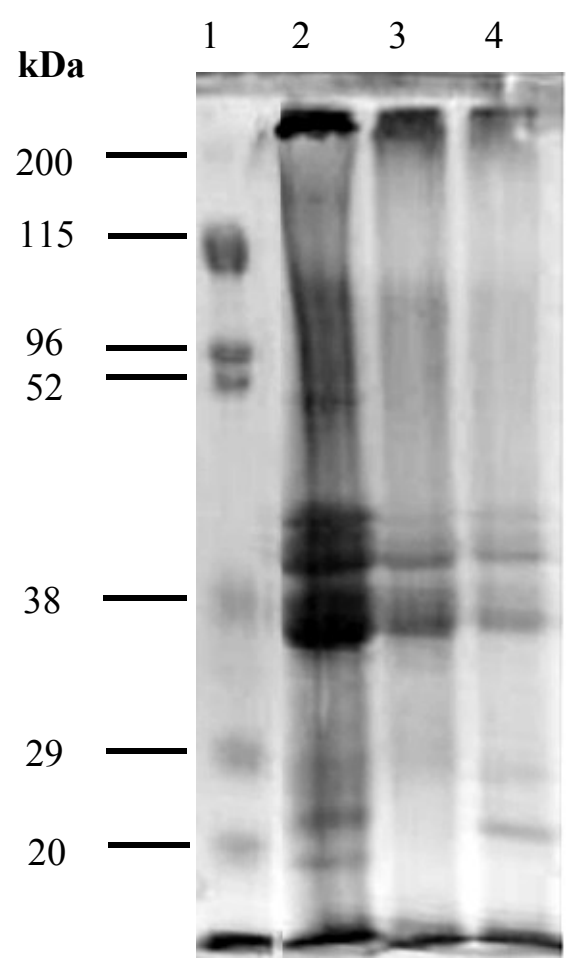

Figure 1. Polyacrylamide gel electrophoresis (10\% SDS-PAGE) of raw whole seed cowpea and its protein isolate with (HPI) and without (NHPI) heating. Lanes (from left to right) correspond to the Molecular mass standard; HPI; NHPI, and raw whole seed cowpea.

Table 2 shows peak attribution to each sample based by the image processing of Figure 1 with the software Image J.

Many foods as legumes, cereals, potatoes, and tomatoes exhibit trypsin inhibitor, an anti-nutritional factor common to beans (FRIEDMAN; BRANDON. 2001). This factor is usually inactivated by heat from 80 to $90{ }^{\circ} \mathrm{C}$, according to the study by Jourdan, Noreña and Brandelli (2007) in Phaseolus vulgaris. Rangel et al. (2004) observed that protein isolated from cowpea by isoelectric precipitation had $60 \%$ reduction of the trypsin inhibitory activity after $80{ }^{\circ} \mathrm{C}$ heating for five minutes. Heating above $90{ }^{\circ} \mathrm{C}$ may lead to aggregation through dissulfide bridges, destroying important protein fractions from cowpea. (PEYRANO; SPERONI; AVANZA, 2016).

The trypsin inhibitor activity (TIU/mg protein) of the whole seed flour (WB) and of the isolates obtained with (HPI) and without (NHPI) heating, are presented in Table 3 .

After isolation, there was a significant reduction of the trypsin inhibitory activity as compared to the whole seed cowpea flour (from $32.5 \pm 0.5 \mathrm{TIU} / \mathrm{mg}$ protein, or $8.0 \pm 0.5 \mathrm{TIU} / \mathrm{mg}$ sample, to $8.30 \pm 0.2 \mathrm{TIU} / \mathrm{mg}$ protein or $7.80 \pm 0.2 \mathrm{TIU} / \mathrm{mg}$ sample, respectively). The whole bean flour presented inhibitory activity inferior to that reported by Jourdan, Noreña and Brandelli (2007) in different cultivars of common bean. Rivas-Vega et al. (2006) found in cowpea trypsin inhibitory activity close to the present study (31.6 TIU/mg proteína or $7.5 \mathrm{TIU} / \mathrm{mg}$ sample. This activity is regarded as low and may be characteristic of the cultivar used by Rivas-Vega et al. (2006) and by the present study. 
Table 2. Molecular mass (MM) and area percent of the peaks detected for raw cowpea whole bean (WB) and its isolates with (HPI) and without (NHPI) heating.

\begin{tabular}{ccccccc}
\hline & \multicolumn{6}{c}{ Sample } \\
\cline { 2 - 7 } Peak n $^{\text {o }}$ & \multicolumn{7}{c}{ HPI } & \multicolumn{2}{c}{ NHPI } \\
\cline { 2 - 7 } & \% area & MM & \% area & MM & \% area & MM \\
\hline 1 & 10.6 & 253.8 & 15.8 & 253.8 & 16.6 & 262.3 \\
2 & - & - & 21.3 & 216.0 & 6.5 & 199.7 \\
3 & 2.1 & 151.3 & - & - & - & - \\
4 & 7.5 & 100.9 & - & - & - & - \\
5 & 4.0 & 94.0 & 10.1 & 96.2 & 10.5 & 95.9 \\
6 & 7.2 & 82.3 & - & - & - & - \\
7 & 7.7 & 73.2 & 9.0 & 76.0 & 6.2 & 76.0 \\
8 & 4.4 & 49.9 & 2.4 & 50.2 & 3.1 & 51.3 \\
9 & 5.1 & 47.4 & - & - & - & - \\
10 & 8.8 & 43.4 & 9.8 & 43.9 & 14.7 & 45.0 \\
11 & 8.7 & 37.8 & 26.0 & 35.5 & 6.2 & 39.8 \\
12 & 18.5 & 33.6 & - & - & 17.1 & 35.6 \\
13 & 1.1 & 21.8 & 1.3 & 23.9 & 1.2 & 22.4 \\
14 & 5.4 & 17.4 & 4.1 & 19.6 & 7.4 & 18.1 \\
15 & 6.6 & 13.4 & - & - & 10.6 & 12.7 \\
16 & 2.3 & 9.2 & - & - & - & - \\
\hline
\end{tabular}

HPI - Protein isolate with heat; NHPI - Non heated protein isolate; WB - Cowpea whole bean flour; $\mathrm{MM}$ - Molecular mass ( $\mathrm{kDa})$.

Table 3. Trypsin inhibitory activity of the whole seed cowpea flour (WB) and its isolates obtained with (HPI) and without (NHPI) heating.

\begin{tabular}{lcc}
\hline Sample & $\begin{array}{c}\text { Trypsin inhibitory activity } \\
\text { (TIU/mg protein)* }\end{array}$ & $\begin{array}{c}\text { Trypsin inhibitor activity } \\
\text { (TIU/mg sample)* }\end{array}$ \\
\hline FI & $32.5 \pm 0.5^{\mathrm{a}}$ & $8.0 \pm 0.5^{\mathrm{b}}$ \\
IPSA & $8.3 \pm 0.2^{\mathrm{c}}$ & $7.8 \pm 0.2^{\mathrm{b}}$ \\
IPCA & $12.7 \pm 0.5^{\mathrm{b}}$ & $10.6 \pm 0.5^{\mathrm{a}}$ \\
\hline
\end{tabular}

Different letters in the same column indicate a significant difference by the Tukey test $(\mathrm{p}<0.05)$.

The low activity of the trypsin inhibitors found in the protein isolates without heating can be explained by the isolation process itself, where this fraction remains in the soluble $\mathrm{pH}$ isoelectric precipitation of the proteins and are discarded (HONIG; RACKIS; WOLF, 1987). In the isolation process with heating the activity was slightly but significantly higher, which can be explained by the co-precipitation of these inhibitors with the majority of the proteins, promoted by heating aggregation. Another possibility is a thermal selection of the less sensitive inhibitors by heating. The importance of the trypsin inhibitors for the nutritive process is because this activity results in more excretion of the digestive enzymes, which are rich in sulfur amino acids. As cowpea proteins are deficient in these amino acids, 
this may represent an important endogenous loss that impacts the nutritional status of population who depends on these proteins (LIENER, 1994).

\section{CONCLUSION}

The isolation process without heating produced an isolated with high content of protein and better yield. It was observed a major change in the molecular profile of the protein from the protein isolates obtained with heating as compared to the isolate produced without heating. The isolation process reduced the trypsin inhibitory activity as compared to the raw whole seed flour. However, heating produced protein isolates with higher activity of trypsin inhibitors, as compared with the non-heated ones. From the nutritional point of view, the isolation process without heating produced superior protein isolates.

\section{ACKNOWLEDGEMENTS}

The authors arte in debt to Dr. Francisco Rodrigues Freire Filho and to "Embrapa Meio-Norte", for providing the cowpea; to the "Fundação de Amparo à Pesquisa do Estado de São Paulo (FAPESP)", for the financial support as scholarship and research grants (Procs. 05/52081-8, 2012/15900-4, and 2016/08758-8).

\section{REFERENCES}

ASSOCIATION OF OFFICIAL ANALYTICAL CHEMISTS - AOAC. Official methods of analysis of AOAC international. Washington. 2007.

BOYE, J.; ZARE, F.; PLETCH, A. Molecular. functional and processing characteristics of whole pulses and pulse fractions and their emerging food and nutraceutical applications. Food Research International, Amsterdam, v. 43, n. 2, p. 414-431, 2010.

BUTT, M. S.; BATOOL, R. Nutritional and functional properties of some promising legumes protein isolates. Pakistan Journal of Nutrition, Dubai, v. 9, n. 4, p. 373-379, 2010.

DEAK, N. A.; JOHNSON, L. A. Effects of extraction temperature and preservation method on functionality of soy protein. Journal of the American Oil Chemists Society, Chicago, v. 84, n. 3, p. 259-268, 2007.

DUARTE, M. S. L. et al. Determination of the trypsin inhibitor activity in vitro of the black bean
(Phaseolus vulgaris L.) albumin and globulin. Alimentos e Nutrição, Araraquara, v. 21, n. 3, p. 373-376, 2010

ELHARDALLOU, S. et al. Amino acid composition of cowpea (Vigna ungiculata L. Walp.) flour and its protein isolates. Food and Nutrition Sciences, Irvine, v. 6, n. 9, p. 790-797, 2015.

FRIEDMAN, M.; BRANDON, D. L. Nutritional and health benefits of soy proteins. Journal of Agricultural and Food Chemistry, Washington, v. 49, n. 3, p. 1069-1086, 2001.

FROTA, K. M. G. et al. Cholesterol-lowering properties of whole cowpea seed and its protein isolate in hamsters. Journal of Food Science. New Jersey, v. 73, n. 9, p. 235-240, 2008.

FROTA, K. M. et al. Cowpea protein reduces LDL-cholesterol and apolipoprotein B concentrations. but does not improve biomarkers of inflammation or endothelial dysfunction in adults with moderate hypercholesterolemia. Nutrición Hospitalaria, Barcelona, v. 31, n. 4, p. 1611-1619, 2015.

FrOTA, K. M. G.; SOARES, R. A. M.; ARÊAS, J. A. G. Composição química do feijão caupi (Vigna unguiculata L. Walp), cultivar BRS-Milênio. Ciência e Tecnologia de Alimentos, Campinas, v. 28, n. 2, p. 470-476, 2008.

HONIG, D. H.; RACKIS, J. J.; WOLF, W. J. Effects of $\mathrm{pH}$ and salt on yields. trypsin inhibitor contends. and mineral levels of soybean protein isolate and whey. Journal of Agricultural and Food Chemistry, Washington, v. 35, n. 6, p. 967-971, 1987.

HORAX, R. et al. Functional properties of protein isolate from cowpea (Vigna unguiculata L. Walp.). Journal of Food Science, Oxford, v. 69, n. 2, p. 119 $-121,2004$.

JOURDAN, G. A.; NOREÑA, C. P. Z.; BRANDELLI, A. Inactivation of trypsin inhibitor activity from Brazilian varieties of beans (Phaseolus vulgaris L.). Food Science and Technology International, London, v. 13, n. 3, p. 195-198, 2007.

KAKADE, M. L.; SIMONS, N.; LIENER, I. E. An evaluation of natural vs synthetic substrates for measuring the antitryptic activity of soybean samples. Cereal Chemistry, Sydney, v. 46, n. 5, p. 518-526, 1969

KALPANADEVI, V.; MOHAN, V. R. Effect of processing on antinutrients and in vitro protein 
digestibility of the underutilized legume. Vigna unguiculata (L.) Walp. subsp. unguiculata. LWTFood Science and Technology, Amsterdam, v. 51, n. 2, p. 455-461, 2013

LAEMMLI, U. K. Cleavage of structural proteins during assembly of the heat of bacteriophage T4. Nature, London, v. 227, n. 5259, p. 680-685, 1970.

LAJOLO, F. M.; GENOVESE, M. Nutritional significance of lectins and enzyme inhibitors from legumes. Journal of Agricultural and Food Chemistry, Washington, v. 50, n. 22, p. 6592-6598, 2002.

LIENER, I. E. Implications of antinutritional components in soybean foods. Critical Reviews in Food Science and Nutrition, Philadelphia, v. 34, n. 1, p. 31-67, 1994.

MARQUES, M. R. et al. Proteolytic hydrolysis of cowpea proteins is able to release peptides with hypocholesterolemic activity. Food Research International, Amsterdam, v. 77, n. 1, p. 43-49, 2015.

PEYRANO, F.; SPERONI, F.; AVANZA, M. V. Physicochemical and functional properties of cowpea protein isolates treated with temperature or high hydrostatic pressure. Innovative Food Science and Emerging Technologies, Amsterdam, v. 33, n. 1, p. 38-46, 2016.

RANGEL, A. et al. Biological evaluation of a protein isolate from cowpea (Vigna unguiculata) seeds. Food Chemistry, Washington, v. 87, n. 4, p. 491-499, 2004.

RAYAS-DUARTE, P.; BERGERON, D.; NIELSEN, S. Screening of heat-stable trypsin inhibitors in dry beans and their partial purification from great Northern beans (Phaseolus vulgaris) using anhydrotrypsin-sepharose affinity chromatography. Journal of Agricultural and Food Chemistry, Washington, v. 40, n. 1, p. 32-42, 1992.

RIVAS-VEGA, M. E. et al. Nutritional value of cowpea (Vigna unguiculata L. Walp.) meals as ingredients in diets for Pacific white shrimp (Litopenaeus vannamei Boone). Food Chemistry, Washington, v. 97, n. 1, p. 41-49, 2006.

RUSSO, R.; REGGIANI, R. Evaluation of protein concentration. amino acid profile and antinutritional compounds in hempseed meal from dioecious and monoecious varieties. American Journal of Plant Sciences, Irvine, v. 6, n. 1, p. 14-22, 2015.
SARWAR, G.; XIAO, C.; COCKELL, K. A. Impact of antinutritional factors in food proteins on the digestibility of protein and the bioavailability of amino acids and on protein quality. The British Journal of Nutrition, London, v. 108, n. 2, p. 315$332,2012$.

SING, B. B. et al. Cowpea genetics: a review of the recent literature. In: Advances in cowpea research. Ibadan: IITA-JIRCAS. 1997. cap. 2. p. 13-15.

UZZAN, A. Vegetable protein products from seeds: technology and uses in food industry. In: HUDSON. B. J. F. (Ed.). Development in Food Proteins. New York: Elsevier Applied Science. 1988. p. 73-118.

WAGNER, J. R.; SORGENTINI, D. A.; ANÕN, M. C. Relation between Solubility and Surface Hydrophobicity as an Indicator of Modifications during Preparation Processes of Commercial and Laboratory-Prepared Soy Protein Isolates. Journal of Agricultural and Food Chemistry, Washington, v. 48 , n. 8 , p. $3159-3165,2000$.

WANG, M. Optimization of extraction process of protein isolate from mung bean Procedia Engineering, Amsterdam, v. 15, n. 1, p. 5250-5258, 2011.

WITHANA-GAMAGE, T. S. et al. Physicochemical. thermal and functional characterization of protein isolates from Kabuli and Desi chickpea (Cicer arietinum L.): a comparative study with soy (Glycine max) and pea (Pisum sativum L.). Journal of the Science of Food and Agriculture, New Jersey, v. 91, n. 6, p. 1022-1031, 2011.

WRIGHT, D. J.; BUMSTEAD, M. R. Legume proteins in food technology. Philosophical Transactions of the Royal Society of London, London, v. 304, n. 1120, p. 381-393, 1984. 